\title{
Detection of Geosmithia morbida on Numerous Insect Species in Four Eastern States
}

\author{
Melanie Moore, ${ }^{1,+}$ Jennifer Juzwik, ${ }^{1}$ Fredric Miller, ${ }^{2}$ Leah Roberts, ${ }^{3}$ and Matthew D. Ginzel ${ }^{4}$ \\ ${ }^{1}$ USDA Forest Service, Northern Research Station, St. Paul, MN 55108 \\ ${ }^{2}$ Research Department, The Morton Arboretum, Lisle, IL 60532 \\ ${ }^{3} 6209$ Wynbrook Way, Raleigh, NC 27612 \\ ${ }^{4}$ Department of Entomology, Purdue University, West Lafayette, IN 47907
}

Accepted for publication 30 May 2019.

\begin{abstract}
Thousand cankers disease is caused by the coalescence of numerous Geosmithia morbida cankers on branches and stems of Juglans species, leading to branch dieback and eventual tree death. The fungus sporulates in galleries of the walnut twig beetle (Pityophthorus juglandis), allowing for acquisition of pathogen propagules and its subsequent transmission to other branches or trees following adult emergence. Recently, G. morbida has been isolated from Xylosandrus crassiusculus and Xyleborinus saxesenii collected in Ohio and Stenomimus pallidus collected in Indiana. These beetles are known to colonize diseased Juglans nigra in these states. In this study, an operational trap survey for ambrosia

beetles, bark beetles, and other weevils was conducted in four eastern states, and captured beetles were assayed to detect $G$. morbida using both culture and PCR-based methods. A new primer pair $(\mathrm{GmF} 3 / \mathrm{GmR} 13)$, based on the $\beta$-tubulin region, was designed for $G$. morbida DNA detection. The pathogen was detected on 18 insect species using molecular methods, and live cultures were isolated from two species. This is the first report of the pathogen in Illinois and Minnesota.

Keywords: diagnostics, trees, thousand cankers disease, Juglans, walnut, beetles, primer pair
\end{abstract}

Thousand cankers disease (TCD) of walnut (Juglans) species results from numerous cankers caused by Geosmithia morbida on branches and main stems of susceptible hosts (Tisserat et al. 2009). The fungus is introduced during attacks of Juglans spp. by its primary vector, the walnut twig beetle (WTB), Pityophthorus juglandis Blackman (Coleoptera: Curculionidae: Scolytinae). Branch dieback and crown death occur after extensive death of the phloem and cambium on branches and stems of affected trees, often taking several years to develop. The causal fungus of the disease was identified and the disease named in 2009 following investigation of widespread death of eastern black walnut in urban settings in Colorado in 2003 and subsequent years (Tisserat et al. 2009). The disease is now known to be present in nine western and five eastern (Maryland, North Carolina, Ohio, Pennsylvania, and Virginia) states. The WTB and the pathogen have been detected in separate locations in Indiana, but diseased trees have not been observed. TCD has been considered a serious threat to health of eastern black walnut and also an economic threat owing to walnut's high monetary value (Newton et al. 2009).

${ }^{\dagger}$ Corresponding author: M. Moore; E-mail: melanie.moore2@usda.gov

Funding: Partial funding for this research was provided by the U.S. Forest Service, Washington Office - Forest Health Protection (Special Projects) and the USDA APHIS Farm Bill Funding Program to North Carolina and Minnesota.

The author(s) declare no conflict of interest.

This article is in the public domain and not copyrightable. It may be freely reprinted with customary crediting of the source. The American Phytopathological Society, 2019.
Detection and monitoring surveys for TCD and/or the WTB have been conducted in multiple eastern states since 2010. These efforts are largely based on guidelines published by the USDA Forest Service and APHIS PPQ (USDA Forest Service and Plant Protection and Quarantine 2018). Insect funnel traps, girdled walnut trap trees, and log baits have been used for these surveys. Lindgren funnel traps baited with a commercially available WTB pheromone lure are most commonly used (Seybold et al. 2013). Collection cups associated with these traps may contain fluids ("wet cups") (e.g., propylene glycol or saline solution) or no fluid ("dry cups"). Stem sections from girdled trap trees or log sections used as bait traps are removed after specified exposure times, placed in emergence tubes or buckets, and any emerged insects regularly collected from dry cups associated with the emergence chamber. Insects obtained from funnel traps with dry cups or from emergence chambers can be used for detection of viable propagules of $G$. morbida or for DNA of the fungus, whereas those from wet cups may only be assayed for fungal DNA owing to the fluid killing the fungi. The pathogen has been isolated from and/or its DNA detected by molecular assay in macerated aqueous suspensions of bark weevils and ambrosia beetles emerged from girdled trap trees or from TCD-symptomatic trees in Indiana and Ohio, respectively (Juzwik et al. 2015, 2016). Thus, several eastern states have recently expanded their WTB monitoring programs to include selected weevil and ambrosia beetle species.

One pathogen detection study (Lamarche et al. 2015) reported on primers (GmF677/GmR878) based on the $\beta$-tubulin gene that were selective and sensitive for G. morbida detection in a real-time PCR protocol. More recently, microsatellite markers have been developed that are specific for the pathogen based on assays 
conducted with wood shavings (Oren et al. 2018). Both these methods required specialized equipment; thus, we devised a PCR assay that was capable of being reproduced in a typical, basic diagnostic lab.

The objective of the study was to assay numerous scolytine and related insects trapped in operational WTB monitoring efforts for the presence of $G$. morbida (viable propagules and/or DNA). The detection of $G$. morbida on multiple ambrosia beetle, bark beetle, other weevils, and two related insect species in four eastern states and the techniques used in the detections are reported here.

\section{Monitoring Sites and Trapping Protocol}

Locations of concern for TCD were selected by cooperators in four eastern states and traps deployed (Fig. 1). In North Carolina, traps were placed near eastern black walnut trees in campgrounds, parks, and wood products businesses in proximity to where TCD

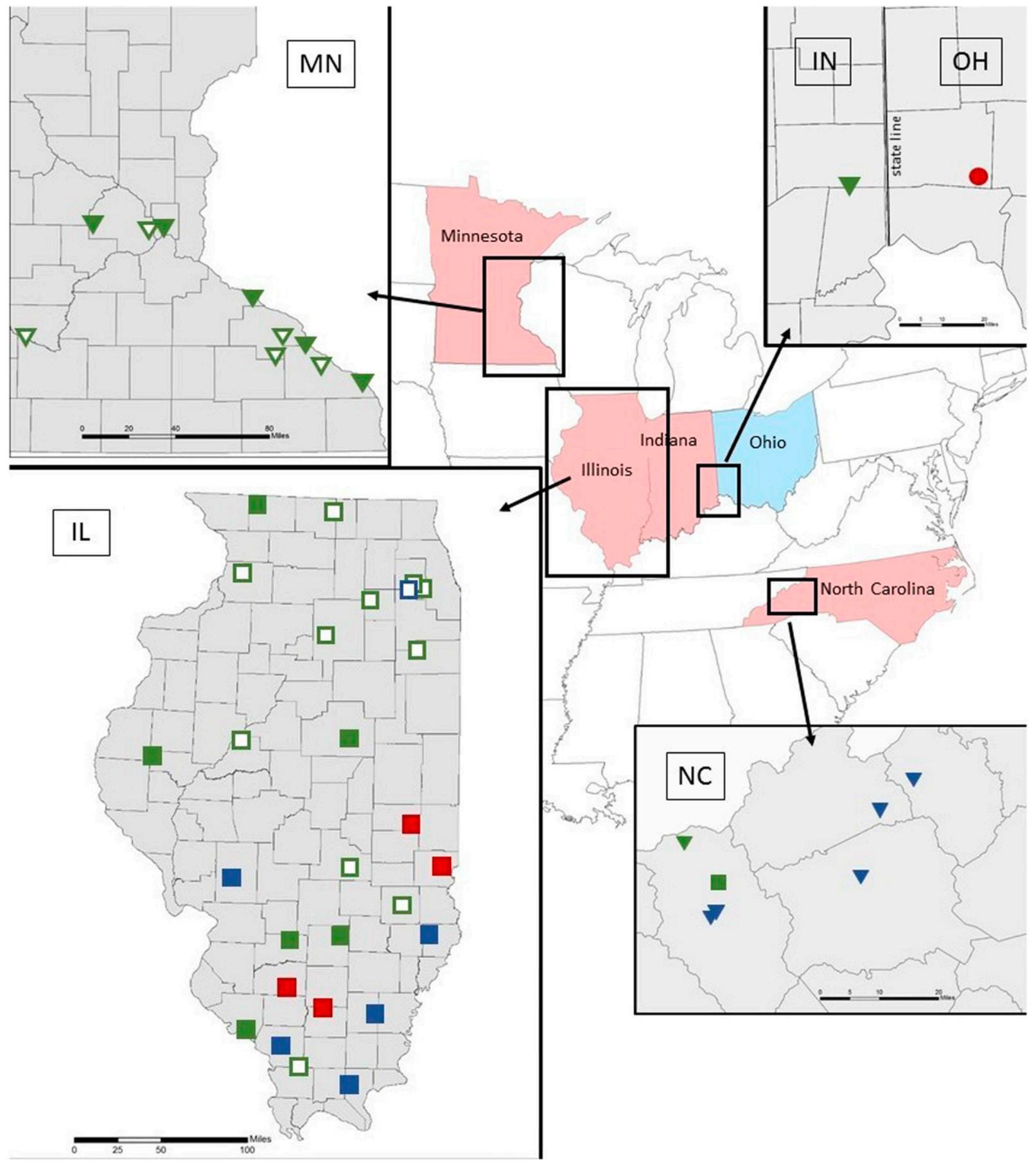

\section{FIGURE 1}

Map of survey areas and locations of traps for collecting insects, 2015 to 2017, for Geosmithia morbida detection assays. States with reported trap surveys are highlighted in red. State with thousand cankers disease (TCD) tree survey (Ohio) highlighted in blue. Symbol color: red = 2015; green = 2016; and blue = 2017 . Symbol shape: $\mathbf{\nabla}=$ Lindgren funnel trap location; $\mathbf{-}=$ trap tree or trap log location; and $\mathbf{0}=$ TCD tree location. Solid shape = positive detection for G. morbida; and outline only shape $=$ no $G$. morbida detected. 
was first detected in the state in 2013. Similarly, in Indiana traps were placed in and near a lumber mill located in Franklin County, which borders the county in Ohio where TCD is established. In Illinois, where TCD has not been detected, black walnut trap trees were chosen in representative parks throughout the state where black walnut is common, as part of TCD early detection surveys. Likewise, in Minnesota, traps were placed in areas where black walnut are common as part of an early detection program. At each location, the primary use of traps was to monitor for WTB, but other insects ("by-catch") such as ambrosia beetles were also captured in the process. Multiple insect species were captured from 2015 through 2017, with the most extensive trapping effort in 2016.

Trap type and timing varied by the needs and interests of the individual state cooperators. Trap trees were small-diameter walnut trees that were girdled early in the growing season (May or June) by two encircling cuts $(15 \mathrm{~cm}$ apart) made into the outer xylem. These trees are attractive to bark-inhabiting beetles that colonize declining trees. In mid-August the trees were felled, and stem sections (approximately $30 \mathrm{~cm}$ long) were placed in emergence buckets. Collection cups were inspected twice per week, and all emerged insects were collected as they appeared. Trap logs were individual branches or small stem sections hung in or near living walnut trees from mid-May to mid-June (about 4 weeks) and then collected and placed in emergence buckets.

Lindgren funnel traps were baited with a commercial WTB pheromone lure and equipped with either wet (antifreeze containing propylene glycol and ethanol) or dry collection cups with kill strips inserted. Most Lindgren traps were deployed in the early summer and the beetles collected every 1 to 2 weeks through mid-July. A 2 -week period of collection was also done in early fall in Minnesota and North Carolina in 2016.

\section{Insect Identification and Assay for Pathogen}

Insect handling. Following collection from traps or emergence buckets, insects were initially frozen, identified to species, and placed singly in $1.5-\mathrm{ml}$ microcentrifuge tubes before being stored at $-20^{\circ} \mathrm{C}$ until further processing. To avoid contamination across insects in an individual collection cup, kill strips were placed in dry collection cups, forceps were sterilized, and new filter paper was used between insects when performing species identification.
Generally, insects were identified to species at labs associated with the surveying agency and then frozen and sent to the St. Paul lab location for the fungal assays. The samples were processed within 6 to 12 months of their collection date.

Individual insects were macerated in a microtube in $30 \mu \mathrm{l}$ of sterile molecular-grade water using a sterile micropestle. Following maceration, three sterile 2-mm glass beads were added to each tube, and the tubes were vortexed for $30 \mathrm{~s}$. For the molecular assay, $110 \mu \mathrm{l}$ of cetyltrimethylammonium bromide (CTAB) lysis buffer was added to each tube (Lindner and Banik 2009), and the tube was frozen at $-20^{\circ} \mathrm{C}$. For beetles used for the dual (both live dilution plating and molecular) assay, $60 \mu \mathrm{l}$ of sterile water was used for the maceration and vortexing. Following maceration, $30 \mu \mathrm{l}$ of the macerate was placed in $110 \mu \mathrm{l}$ of $\mathrm{CTAB}$, and $30 \mu \mathrm{l}$ was used for serial dilution plating (SDP) (described below). Insects from five of the nine collections assayed were obtained from dry cups or emerged from trap trees or logs and used in the dual assay (Table 1).

Detection of $\boldsymbol{G}$. morbida. Half of the macerated insect suspension was used to create a dilution series $(30 \mu l$ of suspension in $300 \mu \mathrm{l}$ of sterile water; $30 \mu \mathrm{l}$ of the first dilution in $300 \mu \mathrm{l}$ of sterile water). Three $100-\mu l$ aliquots of each dilution were dispensed and spread evenly on each of three plates containing quarter-strength potato dextrose agar (PDA) amended with streptomycin and chloramphenicol. Suspect colonies of G. morbida growing on the incubated plates $\left(25^{\circ} \mathrm{C}\right.$; ambient fluorescent lighting) were transferred to half-strength PDA and subcultured as necessary to obtain pure isolates. Small amounts of mycelium were placed in $110 \mu \mathrm{l}$ of CTAB in 0.6- $\mu$ l tubes for DNA extraction and standard PCR (GeneClean with modifications by Lindner and Banik [2009]) using the following primer pair: GmF3, CAGGCGAGGAGAAACGA GAA; and GmR13, GAGTCAGTGTTCTGACCGCA (hereafter referred to as "GmP" primers). This primer pair was developed specifically for G. morbida detection using the $\beta$-tubulin region. PCR products were visualized on $1.5 \%$ agarose gel with ethidium bromide and viewed under UV light. Standard Sanger sequencing and a BLASTn search of the NCBI GenBank database were performed to confirm G. morbida identity using a $97 \%$ cutoff.

Total genomic DNA was extracted from CTAB portions of the above-described macerates using the Lindner and Banik (2009) method. Amplification of extracted DNA was based on the protocol

\begin{tabular}{|c|c|c|c|c|c|}
\hline \multicolumn{6}{|c|}{$\begin{array}{l}\text { TABLE } 1 \\
\text { Sources of insects, years, and trap types used for detection of Geosmithia morbida and comparison of molecular results with } \\
\text { culturing (serial dilution plating [SDP]) method when performed }\end{array}$} \\
\hline \multirow[b]{2}{*}{ State } & \multirow[b]{2}{*}{ Year } & \multirow[b]{2}{*}{ Trap type } & \multirow[b]{2}{*}{ Number of insects assayed } & \multicolumn{2}{|c|}{$\begin{array}{l}\text { Number of insects positive for } \\
\text { G. morbida based on }\end{array}$} \\
\hline & & & & PCR plus DNA sequencing a & SDP \\
\hline Illinois & 2015 & Trap trees & 35 & 11 & $\mathrm{NA}^{\mathrm{b}}$ \\
\hline Minnesota & 2016 & Lindgren funnel, wet cup & 58 & 24 & $\mathrm{NA}^{\mathrm{c}}$ \\
\hline North Carolina & 2016 & Trap logs & 55 & 42 & $\mathrm{NA}^{\mathrm{d}}$ \\
\hline North Carolina & 2016 & Lindgren funnel, dry cup & 246 & 75 & $\mathrm{NA}^{\mathrm{d}}$ \\
\hline North Carolina & 2016 & Lindgren funnel, dry cup & 109 & 41 & 0 \\
\hline Illinois & 2017 & Trap trees & 148 & 69 & 1 \\
\hline
\end{tabular}

${ }^{a} \mathrm{GmP}$ primer assay using primer pair $\mathrm{GmF} 3 / \mathrm{GmR} 13$ and confirmed by Sanger sequencing.

${ }^{b}$ Not applicable: insects were stored in $70 \%$ ethanol after collection; thus, it was not possible to culture fungi.

${ }^{\mathrm{c}}$ Not applicable: insects were trapped in propylene glycol and unable to culture fungi.

${ }^{\mathrm{d}}$ SDP not performed. 
of Juzwik et al. (2015) with the following modifications. In the PCR reaction mixture, each primer (the above-mentioned $\mathrm{GmP}$ primer pair) had a final concentration of $0.4 \mu \mathrm{M}$, and supplemental $25 \mathrm{mM}$ magnesium solution was added to create a final concentration of $2.5 \mathrm{mM}$. No extra water was added to the PCR mix; therefore, all of the water $(9.8 \mu \mathrm{l}$ of the $15 \mu \mathrm{l}$ reaction mixture) was from the original DNA extract, in order to maximize the chance of detecting minute quantities of target DNA. The thermocycler conditions were as follows: initial denaturing at $94^{\circ} \mathrm{C}$ for $10 \mathrm{~min}$; 40 cycles of denaturing at $94^{\circ} \mathrm{C}$ for $40 \mathrm{~s}$, annealing at $53^{\circ} \mathrm{C}$ for $40 \mathrm{~s}$; extension at $72^{\circ} \mathrm{C}$ for $1.5 \mathrm{~min}$; and a final extension step of $72^{\circ} \mathrm{C}$ for $10 \mathrm{~min}$. Visualization of the PCR product was done on a $1.5 \%$ agarose gel with ethidium bromide incorporated under UV light.

Preliminary tests of this method revealed that at very low concentrations the G. morbida DNA was not always detected, and there were occasional false negatives. Therefore, each DNA sample was subjected to PCR with the GmP primers for two equal but independent runs, and a specimen was deemed tentatively positive if at least one run had a distinct band on the agarose gel at approximately $250 \mathrm{bp}$ (Fig. 2). All PCR products were sequenced as described above to confirm G. morbida identity. The most commonly matched (>99\%) GenBank accession number was KJ148224.1. Identification was possible with approximately $86 \%$ certainty for agarose gel bands that were initially visualized as positive, using a $97 \%$ cutoff for sequence match. Approximately $4.4 \%$ of sequences matched G. morbida in the GenBank database, but the match was below the cutoff. Occasionally a tentative positive would not be confirmed owing to unreadable or incomplete sequencing results $(5.4 \%)$. The detection rate increased to $95 \%$ when unreadable sequences were removed and G. morbida

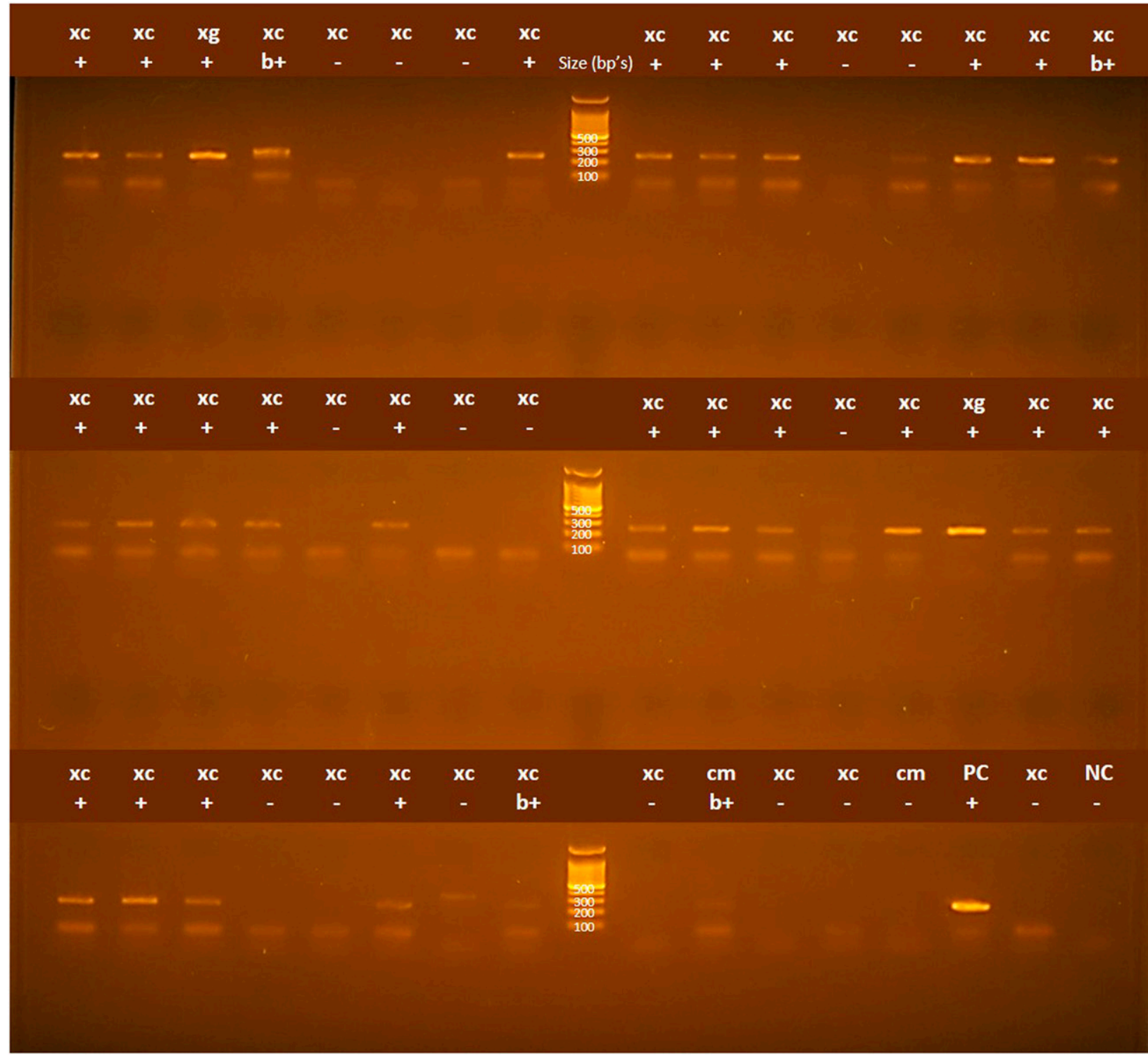

\section{FIGURE 2}

Image of PCR products in a 1.5\% agarose gel following electrophoresis typical of band patterns observed in this study. Products derived from fungal DNA extracted from variously trapped insects. Positive band is approximately $250 \mathrm{bp} . \mathrm{xc}=$ Xylosandrus crassiusculus; $\mathrm{xg}=X . \mathrm{germanus} ; \mathrm{cm}=$ Cnestus mutilatus; $\mathrm{PC}=$ positive control (Geosmithia morbida DNA); NC = negative control water blank; + = positive band; - = negative band (or too faint); and b+ = borderline size or brightness. All positive bands confirmed as $G$. morbida by sequencing using a $97 \%$ cutoff. 
matching sequences under the $97 \%$ cutoff were added. Some $(2.3 \%)$ of the readable sequences did not match any known organism in the database ( $85 \%$ cutoff). Only $1.8 \%$ matched another fungal or bacterial species.

\section{Pathogen Detection on Assayed Insects}

In Illinois, where TCD has not been observed, the rates of $G$. morbida detection on insects collected from trap trees and assayed using the GmP primer assay were 31,25 , and $47 \%$ for collections made in 2015, 2016, and 2017, respectively (Table 1). In Minnesota, another state with no known TCD, the detection rate was $41 \%$ (Lindgren funnel traps, wet cup). In North Carolina, where TCD has been documented, G. morbida DNA was detected using the GmP assay in 2016 on $75 \%$ of assayed beetles from trap logs compared with $35 \%$ of beetles from Lindgren funnel traps with dry cups. Similarly, in 2017, 36\% of the insects from the North Carolina dry cups of funnel traps were positive for G. morbida DNA.

When the SDP procedure was used on a subset of five insect collections (Table 1), G. morbida was detected only twice $(0.26 \%)$ compared with much higher rates found for the same insects using the GmP assay (35\%). The SDP method detects live propagules, whereas the GmP assay detects DNA of live or dead G. morbida. The detected DNA could be coming from nonviable, dead, or even fragmentary sources, but it confirms the presence of G. morbida in the environment.

\section{Assay of Insects from TCD Trees}

Rates of G. morbida detection based on SDP were compared with those from the GmP assay method used for WTB and weevil species collected from emergence buckets containing branch and main stem sections (1.0 m long) of four TCD-symptomatic Juglans nigra (25 to $35 \mathrm{~cm}$ diameter at breast height) in Butler Co., Ohio, in 2015. The previously described dual assay system was used to process 41 weevils (representing four species) and two P. juglandis (Table 2). G. morbida was detected more frequently $\left(\chi^{2} P=0.0283\right)$ using $\mathrm{GmP}(37.2 \%)$ than SDP $(16.3 \%)$. GmP results are based on DNA sequencing. Positive detection by both methods $(11.6 \%)$ was obtained for five specimens represented by three species ( $P$. juglandis, Stenomimus pallidus, and Himatium errans).

TABLE 2
Comparison of Geosmithia morbida detection on adults of
four weevil and one bark beetle (Pityophthorus juglandis)
species by two assay methods

${ }^{a}$ Insects were emerged from branch and main stems sections taken from thousand canker disease-symptomatic Juglans nigra in Ohio, September 2015.

${ }^{\mathrm{b}}$ Dual assay system used for macerated insects suspended in moleculargrade water. $\mathrm{SDP}=$ serial dilution plating on agar medium; and $\mathrm{GmP}=$ extracted fungal DNA amplified with $\mathrm{GmF} / \mathrm{GmR} 13$ primers in PCR reaction, results confirmed by Sanger sequencing.
When comparing results of the SDP method only, the probability of detecting the fungus was greatest for insects obtained in Ohio, where TCD-symptomatic trees occur (16.3\%), compared with Illinois $(0.26 \%)$, where TCD trees have not been found $\left(\chi^{2} P<\right.$ $0.0001)$.

\section{Summary of Insect Species on Which G. morbida Was Detected}

G. morbida (either live propagules via SDP assay or fungus DNA via GmP assay and sequencing) was detected on 18 species of ambrosia beetles, bark beetles, other weevils, and two other taxa through our surveys (Table 3 ). The most frequently trapped and assayed insect species was Xylosandrus crassiusculus. One of the live G. morbida isolates obtained from the Illinois survey collection came from an $X$. crassiusculus specimen, whereas the other was obtained from Pseudopityophthorus minutissimus. Other frequently trapped insects testing positive for G. morbida, from multiple states, include Xyleborinus saxesenii, Xylosandrus germanus, and Monarthrum mali. For insect taxa represented by eight or more individuals, rates of $G$. morbida detection ranged from 15 to $60 \%$, and frequencies of detection were different among these taxa $\left(\chi^{2} P=0.0048\right)$. The highest detection rates were for two species not previously known to colonize walnut and were found in trap trees in Illinois in 2017: the oak bark beetle, $P$. minutissimus (60\%), and the red-shouldered bostrichid, Xylobiops basilaris (56\%). Another species found occasionally to carry $G$. morbida in Illinois in 2017 was Neoclytus acuminatus, the redheaded ash borer, a cerambycid that has been known to colonize walnut (Solomon 1995).

\section{Implications and Conclusions}

The disease known as TCD has been viewed as a disease complex involving the WTB and its symbiotic fungus, G. morbida. First reports of TCD in a state are based on the (i) detection of WTB, (ii) isolation of G. morbida, and (iii) presence of TCD-symptomatic trees (USDA Forest Service and Plant Protection and Quarantine 2018). Previously, G. morbida had been considered a unique associate of the WTB, which is native to the southwestern United States and invasive to newly detected areas. However, the discovery of G. morbida on the insect S. pallidus in Indiana in the absence of symptomatic walnut trees (Juzwik et al. 2015) led to the hypothesis that the G. morbida/WTB association was not unique and G. morbida may be more widespread in the United States than previously considered. Our current findings provide further evidence for "de-coupling" G. morbida from WTB.

New evidence has been reported that G. morbida DNA has also been found on ambrosia beetles captured by Lindgren funnel traps in Missouri (Doerhoff and Diesel 2018). Detections were based on results of assays using the $\mathrm{GmP}$ primers and were confirmed by sequencing (Josephine Mgbechi-Eseri, personal communication). To date, G. morbida DNA has been detected on non-WTB insects in five states, and live propagules have been found in two. The fact that G. morbida DNA has now been found in so many locations supports the hypothesis that the fungus may be widespread throughout the eastern United States and occurs in the absence of TCD-symptomatic walnut or WTB.

Live, culturable G. morbida has now been detected on three insect species in non-TCD areas: S. pallidus (Juzwik et al. 2015) and now $X$. crassiusculus and $P$. minutissimus. However, the frequency of the pathogen isolation has been rare from dispersing insects captured as "by-catch" in WTB pheromone-baited traps or emerged from trap trees or logs. In contrast, G. morbida has been 
TABLE 3

Insects for which Geosmithia morbida DNA was detected using the GmP primer assay ${ }^{a}$

Insect classification

Insect species Common name category

Subfamily

Number of insects

Xylosandrus crassiusculus

Xyleborinus saxesenii

Xylosandrus germanus

Monarthrum mali

Pseudopityophthorus minutissimus

Cnestus mutilatus

Ambrosiophilus atratus

Monarthrum fasciatum

Ambrosiodmus obliquus

Xyleborus californicus

Pityophthorus juglandis

Himatium errans

Stenomimus pallidus

Stenoscelis brevis

Conotrachelus retentus

Dryophthorus americanus

Xylobiops basilaris

Neoclytus acuminatus
Ambrosia beetle

Ambrosia beetle

Ambrosia beetle

Ambrosia beetle

Bark beetle

Ambrosia beetle

Ambrosia beetle

Ambrosia beetle

Ambrosia beetle

Ambrosia beetle

Bark beetle

Other weevils

Other weevils

Other weevils

Other weevils

Other weevils

Powder-post beetle

Long horned beetle
Scolytinae

Scolytinae

Scolytinae

Scolytinae

Scolytinae

Scolytinae

Scolytinae

Scolytinae

Scolytinae

Scolytinae

Scolytinae

Cossoninae

Cossoninae

Cossoninae

Molytinae

Dryophthorinae

Bostrichinae

Cerambycinae
G. morbida-positive

Total assayed

250

77

12

9

18

11

4

3

1

1

1

4

8

1

3

1

18

4

${ }^{a}$ Results are combined from trap catches in four states over three years and assay results confirmed by DNA sequencing.

${ }^{\mathrm{b}}$ Extracted fungal DNA amplified with $\beta$-tubulin primers in $\mathrm{GmP}(\mathrm{GmF} / \mathrm{GmR} 13)$ PCR reaction and results confirmed by Sanger sequencing.

commonly isolated from WTBs and several ambrosia beetle and weevil species emerged from TCD-affected walnut trees (Juzwik et al. 2016; this study; Moore and Juzwik, unpublished data), suggesting that the fungus is cryptic, doing little or no damage unless introduced into the numerous wounds created by the WTB.

In this study, G. morbida DNA was found on 18 species of insects, indicating the fungus has at least casual contact on a broad range of species. The granulate ambrosia beetle, X. crassiusculus, was by far the most common insect intercepted on or near eastern black walnut in our studies. This species is a widespread invasive pest that has been present in the eastern United States since at least 1974, and it has been implicated as a destructive pest of fruit trees and ornamentals, capable of mass attacking small trees (Ranger et al. 2016). X. crassiusculus has recently been reported on stressed $J$. nigra, as have $X$. saxesenii and X. germanus (Reed et al. 2015), two of the more frequently captured species in our study. $X$. germanus is also a widespread pest that has been in the United States since at least 1932 and is known to damage black walnut in nursery settings (Ranger et al. 2010; Weber and McPherson 1983). For any of these insects to be a major contributor to the TCD problem, however, they would have to consistently carry live $G$. morbida propagules as well as being capable of introducing enough inoculum through mass attack to affect the health of mature black walnut trees. At the present time, WTB alone is known to transmit the canker fungus to apparently healthy eastern black walnut trees. The relative importance of these other species in transmission of the pathogen and subsequent TCD development is not known and warrants further investigation.

Lastly, we developed a primer pair based on the $\beta$-tubulin gene for use within a traditional PCR protocol to detect DNA of $G$. morbida. This primer pair is a significant improvement over previously published tools that utilize the internal transcribed spacer (ITS) region. We were unable to devise a primer pair using the ITS region that was specific enough to detect G. morbida alone (unpublished results). This is consistent with other researchers' observations that the ITS region is not sufficiently informative to distinguish certain Geosmithia species (Kolařík et al. 2017). An $86 \%$ accuracy level for detection of G. morbida was determined for this protocol based on DNA sequencing results. Our protocol is suitable for use by plant disease diagnostic laboratories with basic molecular biology equipment; however, it requires DNA sequencing of the PCR product for confirming G. morbida. The sequencing confirmation is particularly important for regulatory situations and first detections in a state.

\section{Acknowledgments}

We gratefully thank the following individuals for their assistance with this study: (i) Angie Ambourn (Minnesota Department of Agriculture) for collecting and identifying insects for Minnesota trapping survey, (ii) Tyler Stewart for identification of the insects from Illinois and Indiana, and (iii) Jacob Botkin for laboratory processing of the Illinois and North Carolina beetles. The careful review of this manuscript by James Jacobs (USDA Forest Service, Forest Health Protection) and suggestions for improvement are gratefully acknowledged.

\section{Literature Cited}

Doerhoff, R., and Diesel, N. 2018. Geosmithia morbida detected in MO. University of Missouri Extension, Agric. Elec. Bull. Board 22(3): Fall 2018. http://agebb.missouri.edu/agforest/archives/v22n3/gh2.php.

Juzwik, J., Banik, M. T., Reed, S. E., English, J. T., and Ginzel, M. D. 2015. Geosmithia morbida found on weevil species Stenominus pallidus in Indiana. Plant Health Prog. 16:7-10.

Juzwik, J., McDermott-Kubeczko, M., Stewart, T. J., and Ginzel, M. D. 2016. First report of Geosmithia morbida on ambrosia beetles emerged from thousand cankers-diseased Juglans nigra in Ohio. Plant Dis. 100:1238.

Kolařík, M., Hulcr, J., Tisserat, N., De Beer, W., Kostovčík, M., Kolaříková, Z., Seybold, S. J., and Rizzo, D. M. 2017. Geosmithia associated with bark beetles and woodborers in the western USA: Taxonomic diversity and vector specificity. Mycologia 109:185-199.

Lamarche, J., Potvin, A., Pelletier, G., Stewart, D., Feau, N., Alayon, D. I. O., Dale, A. L., Coelho, A., Uzunovic, A., and Bilodeau, G. J. 2015. Molecular detection of 10 of the most unwanted alien forest pathogens in Canada using real-time PCR. PLoS One 10:e134265. 
Lindner, D. L., and Banik, M. T. 2009. Effects of cloning and root-tip size on observations of fungal ITS sequences from Picea glauca roots. Mycologia 101:157-165.

Newton, L., Fowler, G., Neeley, A. D., Schall, R. A., and Takeuchi, Y. 2009. Pathway assessment: Geosmithia sp. and Pityophthorus juglandis Blackman movement from the western into the eastern United States. U.S. Department of Agriculture, Animal and Plant Health Inspection Service, Washington, DC. https://agriculture.mo.gov/plants/pdf/tc_pathwayanalysis.pdf

Oren, E., Klingeman, W., Gazis, R., Moulton, J., Lambdin, P., Coggeshall, M., Hulcr, J., Seybold, S. J., and Hadziabdic, D. 2018. A novel molecular toolkit for rapid detection of the pathogen and primary vector of thousand cankers disease. PLoS One 13:e0185087.

Ranger, C. M., Reding, M. E., Persad, A. B., and Herms, D. A. 2010. Ability of stress-related volatiles to attract and induce attacks by Xylosandrus germanus and other ambrosia beetles. Agric. For. Entomol. 12:177-185.

Ranger, C. M., Reding, M. E., Schultz, P. B., Oliver, J. B., Frank, S. D., Addesso, K. M., Hong Chong, J., Sampson, B., Werle, C., and Gill, S. 2016. Biology, ecology, and management of nonnative ambrosia beetles (Coleoptera: Curculionidae: Scolytinae) in ornamental plant nurseries. J. Integr. Pest Manag. 7: $1-23$.
Reed, S. E., Juzwik, J., English, J. T., and Ginzel, M. D. 2015. Colonization of artificially stressed black walnut trees by ambrosia beetle, bark beetle, and other weevil species (Coleoptera: Curculionidae) in Indiana and Missouri. Environ. Entomol. 44:1455-1464.

Seybold, S. J., Dallara, P. L., Hishinuma, S. M., and Flint, M. L. 2013. Detecting and identifying the walnut twig beetle: Monitoring guidelines for the invasive vector of thousand cankers disease of walnut. http://ipm.ucanr.edu/PDF/ PESTNOTES/WTB_trapping.pdf

Solomon, J. D. 1995. Guide to insect borers in North American broadleaf trees and shrubs. Forest Service Agriculture Handbook AH-706. U.S. Department of Agriculture, Washington, DC.

Tisserat, N., Cranshaw, W., Leatherman, D., Utley, C., and Alexander, K. 2009. Black walnut mortality in Colorado caused by the walnut twig beetle and thousand cankers disease. Plant Health Prog. 10. doi: 10.1094/PHP-2009-0811-01-RS.

USDA Forest Service and Plant Protection and Quarantine. 2018. Thousand cankers disease survey guidelines for 2018. https://www.fs.fed.us/foresthealth/ applied-sciences/news/2018/tcd_guidelines.shtml

Weber, B. C., and McPherson, J. E. 1983. Life history of the ambrosia beetle Xylosandrus germanus (Coleoptera: Scolytidae). Ann. Entomol. Soc. Am. 76: 455-462. 